\title{
Aluminum in Effluents and Sludges from the Preliminary Coagulation in Dairy Factory Aerated Balancing Tanks: An Analytical and Sorption Study
}

\author{
Michał Sadowski (D), Piotr Anielak $(\mathbb{D}$, and Wojciech M. Wolf \\ Institute of General and Ecological Chemistry, Faculty of Chemistry, Lodz University of Technology, 116 Zeromskiego Street, \\ 90-924 Lodz, Poland \\ Correspondence should be addressed to Michał Sadowski; michal.sadowski@edu.p.lodz.pl
}

Received 15 April 2018; Revised 1 November 2018; Accepted 8 November 2018; Published 4 December 2018

Academic Editor: Hassan Arida

Copyright (C) 2018 Michał Sadowski et al. This is an open access article distributed under the Creative Commons Attribution License, which permits unrestricted use, distribution, and reproduction in any medium, provided the original work is properly cited.

\begin{abstract}
The coagulation process is used as the first step for the chemical treatment of liquid waste. Resulting wet sludge is treated with coagulants or polyelectrolytes to improve dewatering characteristics of its so-called conditioning. The coagulants such as aluminum sulphate or polyaluminum chloride $\left(\mathrm{Al}_{2} \mathrm{Cl}_{n}(\mathrm{OH})_{6-n}\right)$ are widely used for dairy wastewater treatment systems. The pretreatment dairy sludge can be applied in agriculture as fertilizer containing valuable nutrients. Hence, a simple, cost effective, and rapid method for the determination of aluminum content in the sludge is essential for calculation of the appropriate coagulant dose at the sludge pretreatment process. In this paper either colorimetric or atomic absorption spectrometric methods as applied for the determination of aluminum concentration in the dairy wastewater are compared. For colorimetric method, the optimum experimental conditions such as $\mathrm{pH}$, reaction time, and concentration of other ions in the sample were determined. The sorption isotherms of aluminum on the activated sludge were determined for diverse aluminum species.
\end{abstract}

\section{Introduction}

Dairy manufacturing has become one of the fastest growing and most profitable sectors of food industry in Poland. Domestic milk production approached $12.9 \mathrm{mln}$ liters in 2015 [1]. Unfortunately, dairy farms and factories are also one of the largest sewage producers in Poland. Assuming that each $1 \mathrm{~m}^{3}$ of processed milk provides almost $3.2 \mathrm{~m}^{3}$ of wastewater, it can be extrapolated that total amount of dairy sewage in 2015 approached $41.3 \mathrm{mln}$ liters [2].

The coagulation process is widely used as the first step for chemical treatment of liquid waste. Resulting wet sludge is treated with coagulants or polyelectrolytes in a process known as conditioning to improve its dewatering characteristics. The coagulants such as aluminum sulphate or polyaluminum chloride are commonly used for dairy wastewater treatment systems to enhance sedimentation rate of organic matter. The European Union promotes usage of the sewage sludge in agriculture [3]. The utilization by the thermal treatment i.e., pyrolysis, gasification, or combustion is also supported [4]. This also concerns aluminum ions because in relatively low concentrations, they may become toxic either to plants or to the aquatic environment. Aluminum and its compounds can interact with metals and nonmetals leading to changes in the biological availability of essential elements which are necessary for the proper functioning of living organisms. Dewatered dairy sludge is an important source of inorganic and organic nutrients and may be used in agriculture for the soil fertilization and improvement. Therefore, a simple, cost effective, and rapid method for the determination of aluminum content in the sludge is essential for calculation of the appropriate coagulant dose at the sludge pretreatment process. It may also be useful for controlling the final aluminum level just before the soil fertilization.

For many years, the basic analytical method being used to determine the concentration of aluminum in industrial wastewater was the colorimetric analysis. It is based on the 
well-recognized ability of aluminum to form colourful complexes with organic compounds such as eriochrome cyanine $\mathrm{R}$ ( $3^{\prime \prime}$-sulfo-3,3'-dimethyl-4-hydroxyfuchson-5, $5^{\prime}$ dicarboxylic (ECR)) (Figure 1), catechol violet [5], or aluminon [6].

Nowadays, modern analytical techniques such as atomic absorption spectrometry (AAS) and inductively coupled plasma spectrometry (ICP) have challenged classic colorimetric analysis. Both methods are quite expensive and require considerable expertise. In this study, aluminum concentration in wastewater has been determined by modified spectrophotometric method which is characterized by good precision, high reproducibility, low cost, and simplicity. Flame and graphite furnace atomic absorption spectrometries [7] were used as reference methodologies.

Aluminum is an amphoteric element with the lowest solubility at neutral $\mathrm{pH}$, when it precipitates as aluminum hydroxide $\mathrm{Al}(\mathrm{OH})_{3}$. Its solubility increases in either acidic or alkaline solutions. Aluminum can form complexes with ECR giving stable compounds such as $\mathrm{Al}-\mathrm{ECR}_{3}$ or $\mathrm{Al}-\mathrm{ECR}_{2} \mathrm{OH}$ in the range of pH 5 to 6 [8] (Figure 2). Therefore, during the analysis, it is necessary to take into account the impact of solution $\mathrm{pH}$ on the structure of aluminum-ECR complexes.

An important issue affecting the metals' determination in complex samples is the interfering effect of matrix components, especially in highly saline samples, including seawaters, dialysis solutions, or mineralisates. This matrix effect can be corrected by the careful sample mineralization and the standard addition calibration method. The $\mathrm{pH}$ optimization for the signal to noise enhancement is mandatory [9].

\section{Experimental}

2.1. The Dairy Sewage Materials. The examined sewage was generated in the production of cottage cheese in the dairy factory located in Lodz region. Postproduction sewage is drained to the factory sewage pretreatment plant, which consists of three aerated balancing tanks followed by the sedimentation tank. Aluminum coagulants were added to the former to keep the $\mathrm{pH}$ at the 6.5 level. Wastewater was discharged into the municipal sewage system after the fourday treatment time. Samples were collected from balancing tanks in a two-week period over the whole 2017 year.

2.1.1. The pH Optimization. The experimental studies were carried out to get the information about impact of acetate buffer concentration and $\mathrm{pH}$ value on spectrophotometric ECR method for determination of aluminum content in dairy sewage samples. The correct solution $\mathrm{pH}$ was maintained by using acetate buffer. The various concentrations of acetate buffer as well as different ratios of buffer components were investigated. The buffer was prepared by mixing $\mathrm{CH}_{3} \mathrm{COONa} \cdot 3 \mathrm{H}_{2} \mathrm{O}$ with $\mathrm{CH}_{3} \mathrm{COOH}$ (Chempur, Piekary Sl., Poland).

2.1.2. Measurements of the UV-Vis Spectra. Maximum absorbance wavelength for both eriochrome cyanine $\mathrm{R}$ and

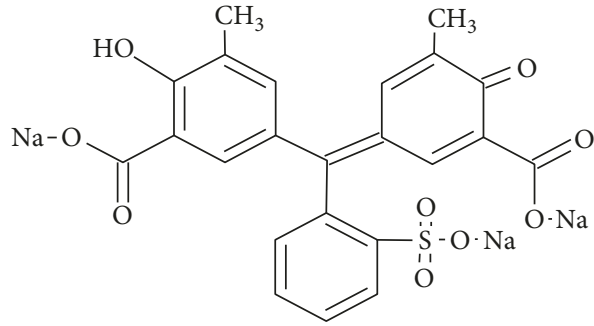

FIGURE 1: The chemical structure of eriochrome cyanine R (ECR).

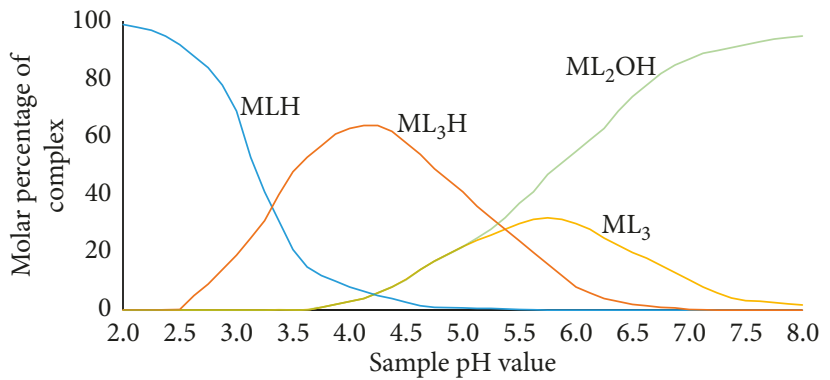

FIgUre 2: The types of complexes $\mathrm{Al}^{3+}$-ECR depending on solution $\mathrm{pH}, \mu=0.1 \mathrm{M} \mathrm{KNO}_{3}$ [8].

complex of Al-ECR was determined. The ECR was supplied by POCH (Gliwice, Poland). The spectra were measured on a UV-Vis spectrophotometer (2041-PC, Shimadzu, Japan). The reference sample was deionized water, and the analyzed samples contained aluminum in the form of either $\mathrm{KAl}\left(\mathrm{SO}_{4}\right)_{2} \cdot 12 \mathrm{H}_{2} \mathrm{O}$ (Chempur) or polyaluminum chloride (Kemira PAX) at concentration of 7.4.1 $10^{-2} \mathrm{mM}$. The samples were prepared in accordance with the procedure for determining the aluminum content in environmental samples as described in the Polish Standard [10].

2.1.3. Mineralization of the Samples. Due to the high content of organic compounds in the samples, the dried samples of the dairy sludge were mineralized before the aluminum content was determined. The each sludge mineralization was made by closed microwave reaction system Multiwave 300 (Anton Paar, USA). The average mass of the tested samples was about $0.1 \mathrm{~g}$. The mixture of $6: 1 \mathrm{~mL}$ (86.6 $\mathrm{mM} \mathrm{HNO}_{3}$ (Chempur) and $11.7 \mathrm{mM} \mathrm{HCl}$ (Chempur)) was applied. In the next step, the mineralisates were filled up to $100 \mathrm{ml}$ with deionized water. The same acid mixture was also added in the course of preparing the calibration curves for mineralisates. The oxidative effect of $\mathrm{HNO}_{3} / \mathrm{HCl}$ mixture on absorbance of emergent complex $\mathrm{Al}-\mathrm{ECR}_{3}$ was also investigated. The acid mixture concentration used for calibration curves was gradually increased from $0.1 \mathrm{mM}$ to $10 \mathrm{mM}$. The constant aluminum and the ECR doses $\left(7.4 \cdot 10^{-2}\right.$ and $3.73 \cdot 10^{-2} \mathrm{mM}$, respectively) were applied.

2.1.4. Measurements of the Absorption Colorimetric Complex. The absorption intensity of the tested aluminum complex was measured using Spekol 11 colorimeter (Carl-Zeiss, Jena, 
Germany). Samples for analysis were prepared in accordance with the procedure described in Polish Standards [10], taking into account the differences in concentrations of acetate buffer dependent on type of sample physical state and organic matter content. When determining the $\mathrm{Al}$ concentration in samples of nonmineralized supernatant liquid, sulfuric acid was used $(0.01 \mathrm{M})$, while in other samples, it was used a mixture of nitric acid and hydrochloric acid $(0.05 \mathrm{M})$. All $\mathrm{pH}$ value measurements were made by a $\mathrm{pH}$ meter (Model N-517, Mera-Elwro, Poland).

In colorimetric method, it is necessary to prepare calibration curves before every analysis. It is the simplest way to reduce influence of random errors on the analysis. For aluminum determination in concentration range of $0.01-0.50 \mathrm{mg} \cdot \mathrm{L}^{-1}$ was prepared a calibration curve following the procedure as described in Hermanowicz et al. [11]. The calibration solutions were obtained by dissolving $\mathrm{KAl}\left(\mathrm{SO}_{4}\right)_{2} \cdot 12 \mathrm{H}_{2} \mathrm{O}$ (Chempur) in double distilled water. The absorbance was measured at $535 \mathrm{~nm}$ against a blank solution containing only the reagents used in analysis.

The formation of the $\mathrm{Al}(\mathrm{ECR})_{3}$ complex takes place in $\mathrm{pH}$ range 5.0-6.0. The $\mathrm{pH}$ value of supernatant liquor was adjusted to the optimum range by adding sulfuric acid $(0.01 \mathrm{M})$, according to the Polish Standard [10] and Hermanowicz et al. [11]. The ECR concentration in all studies was kept constant at $3.73 \cdot 10^{-2} \mathrm{mM}$ [12].

Based on earlier studies on the Al-ECR complex stability [6] as well as our own analyses, it was concluded that the most intensive signal appeared in 10 min after adding the eriochrome reagent. This time was applied to all investigated samples.

2.1.5. The Filtered Supernatant Liquid. In the first step, dairy slurry was homogenized by magnetic stirrer and then was filtered through the medium filter paper. The aluminum residual content in filtrate was determined by graphite furnace atomic adsorption spectrometry (GFAAS). The aluminum concentration never exceeded the value of $0.015 \mathrm{mg} \cdot \mathrm{L}^{-1}$. The difference between the blank sample containing the supernatant and the blank sample for deionized water was subtracted from analysis data.

2.2. Atomic Absorption Spectrometry. The basic methods to determining aluminum content in sewage sludge are instrumental techniques mainly based on atomic absorption spectrometry. The Polish Standard [7] recommends using the flame atomic absorption spectrometry (FAAS) for determining the concentration of aluminum in the range from $5 \mathrm{mg} \cdot \mathrm{L}^{-1}$ to $100 \mathrm{mg} \cdot \mathrm{L}^{-1}$. The content of aluminum was analyzed by Thermo Elemental SOLAAR S2 Flame AA Spectrometer (Thermo Scientific, Waltham, USA). Studies have shown that at concentrations above $5 \mathrm{mg} \cdot \mathrm{L}^{-1}$, this method is completely satisfactory. At low concentrations, less than $4 \mathrm{mg} \cdot \mathrm{L}^{-1}$, the accuracy of the assay is unsuitable, and $\mathrm{SD}$ value reaches exceeding $5 \%$. The graphite furnace atomic absorption spectrometry (GFAAS) is recommended for small or trace aluminum contents, from 0.01 to
$0.1 \mathrm{mg} \cdot \mathrm{L}^{-1}$ [7]. GFAAS spectrometer Sensa AA (GBC Scientific Equipment, Braeside, VIC, Australia) was applied. The introduced division is applied to analyze both sewage sludge samples and supernatant liquid.

Graphite furnace atomic absorption spectrometry is a method based on atomization of aluminum as a result of heating the graphite tube. The nitrous oxide-acetylene flame is a oxidant/fuel combination, which has a maximum temperature of about $2900^{\circ} \mathrm{C}$ [13]. The liquid aluminum sample was heated stepwise (up to $2500^{\circ} \mathrm{C}$ for 5.0 seconds) to evaporate [14]. Aluminum determination was made at an excitation wavelength of $309.35 \mathrm{~nm}$, at a slit width of $0.5 \mathrm{~nm}$ [7]. All atomic absorption measurements were made, using a single-element aluminum hollow-cathode lamp (Photron, Narre Warren, Australia). The GFAAS calibration curves were prepared by adequate dilutions of a $1000 \mathrm{mg} \cdot \mathrm{L}^{-1}$ aluminum standard solution for ASS (Merck, Germany) in range $0.01 ; 0.05 ; 0.10 \mathrm{mg} \cdot \mathrm{L}^{-1}$.

The main disadvantage in GFAAS aluminum analysis is matrix interference and the formation of refractory carbides [15]. From among three chemical modifiers, i.e., phosphoric acid (Chempur) [16], $\mathrm{Mg}\left(\mathrm{NO}_{3}\right)_{2}$ (Merck) [17], and $\mathrm{Pd}\left(\mathrm{NO}_{3}\right)_{2}$ (Merck), the last was chosen. The mixture of $\mathrm{Pd}\left(\mathrm{NO}_{3}\right)_{2} / \mathrm{Mg}\left(\mathrm{NO}_{3}\right)_{2}$ as a chemical modifier is recommended too $[18,19]$. $\mathrm{Pd}\left(\mathrm{NO}_{3}\right)_{2}$ can be used to stabilise $\mathrm{Al}$ ions at higher pyrolysis temperature [20]. Palladium modifier gives correct results of aluminum content, when the samples have low silica content [21]. The interference of easily decomposing chlorides was eliminated by a nitric acid acidification of the sample [22].

\section{Results and Discussion}

3.1. The Colorimetric Method. Maximum absorbance wavelength was determined for both eriochrome cyanine $\mathrm{R}$ and Al-ECR complex. As shown in Figure 3, the absorption spectrum of ECR has maximum absorbance at wavelength of $440 \mathrm{~nm}$, and for Al-ECR complex, the absorption peak is shifted to longer wavelengths $(535 \mathrm{~nm})$.

3.2. The Buffer Capacity of the System. Following Hermanowicz et al. [11], the acetate buffer at concentration $0.20 \mathrm{M}$ was used to obtain $\mathrm{pH}=6.15$, but the standard method for spectrophotometric determination of aluminum recommends the usage of stronger acetate buffer of $0.46 \mathrm{M}$, which gives $\mathrm{pH}=6.35$ [10]. This issue is of particular importance when applied strongly acidic mixtures in the microwave mineralization when the capacity of the weaker acetate buffer was practically exhausted (Figure 4).

The acid concentration above $6 \mathrm{mM}$ leads to decomposition of the chromogenic reagent if a weaker acetate buffer was used. The stronger buffer solution of $0.46 \mathrm{M}$ was sufficient to neutralize the damaging acid impact.

The solutions' $\mathrm{pH}$ values in this analysis were within range from 6.7 to 2.5 , and the maximum solution absorbance occurred at $\mathrm{pH}$ of 6.1 when the most stable complexes between aluminum and triple molecules ECR-like ligands are formed [8]. The absorbance decreases with increase of 


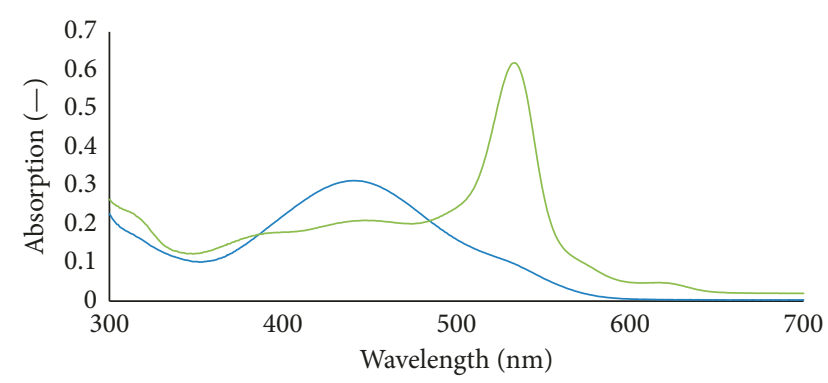

FIGURE 3: Spectra of eriochrome cyanine R (blue) and Al-ECR complexes (green) against distilled water with the following conditions: $\mathrm{pH}, 5.20$; acetate buffer, $0.2 \mathrm{M} ; \mathrm{Al}^{3+}, 7.4 \cdot 10^{-2} \mathrm{mM}$.

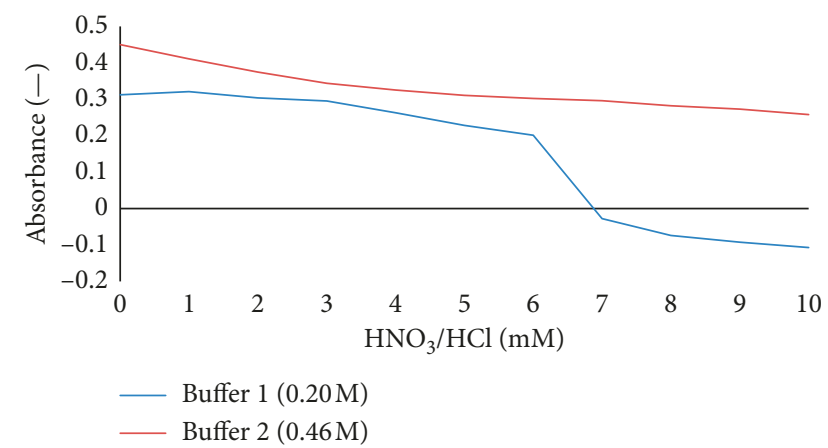

FIgURE 4: The effect of acid concentration on absorbance.

the hydrogen ion concentration, and finally the oxidation of ECR occurs at the $\mathrm{pH}$ value $3.5-3.7$ (Figure 5).

Figure 6 shows the influence of acetate buffer concentration on the absorbance of the $\mathrm{Al}(\mathrm{ECR})_{3}$ complex. The concentration of a $\mathrm{HCl}$ and $\mathrm{HNO}_{3}$ mixture was fixed at $1.74 \mathrm{mM}$ for all analysis in this experiment.

The buffer at concentration of $0.20 \mathrm{M}$ gives a higher absorbance values, despite lower $\mathrm{pH}$ of the sample, i.e., 5.17 \pm 0.03 . The stronger buffer $(0.46 \mathrm{M})$ allows to obtain $\mathrm{pH}$ value of $5.55 \pm 0.05$. However, its greater ionic strength disturbs the ECR complex formation and, in effect, reduces the sensitivity of absorbance measurements.

As shown in Figure 7, the buffer concentration has an impact on the absorbance value, but has no influence on the optimum wavelength for particular measurement. The red line corresponds to the high $\mathrm{pH}$ and high concentration of the acetate buffer $(0.46 \mathrm{M})$, while the blue and green lines represent absorbance obtained with the $0.20 \mathrm{M}$ buffer.

\subsection{The Organic Matter in ECR Colorimetric Method.} Three calibration curves were prepared by diluting the standard aluminum solution in the form $\mathrm{KAl}\left(\mathrm{SO}_{4}\right)_{2} \cdot \mathrm{H}_{2} \mathrm{O}$. The first curve (series 1) was made according to the Polish Standard [10], in a range of aluminum concentrations from $0.07 \mathrm{mg} \cdot \mathrm{L}^{-1}$ to $0.49 \mathrm{mg} \cdot \mathrm{L}^{-1}$. The second curve (series 2 ) was prepared in a similar way but instead deionized water, $20 \mathrm{ml}$ of supernatant liquid was added. The third curve (series 3 ) was based on the supernatant liquid and treated by mineralization according to the Polish Standard [10], where

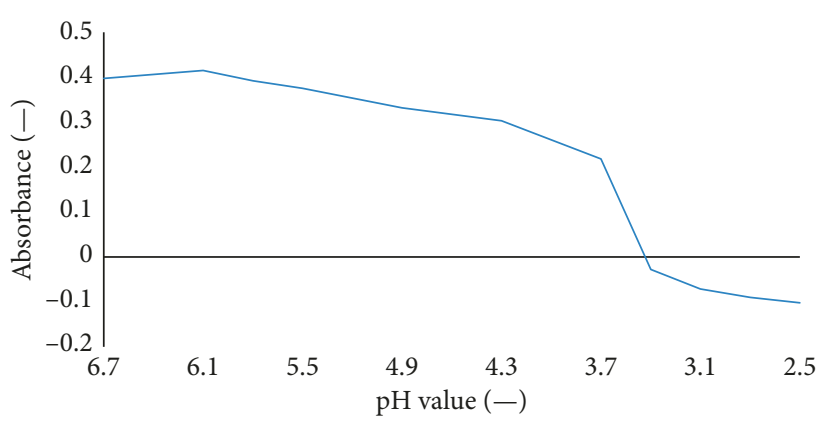

FIGURE 5: The $\mathrm{pH}$ effect on $\mathrm{Al}-\mathrm{ECR}_{3}$ signal intensity: acetate buffer $\left(0.2 \mathrm{M} \mathrm{Al}^{3+}\left(7.4 \cdot 10^{-2} \mathrm{mM}\right)\right)$.

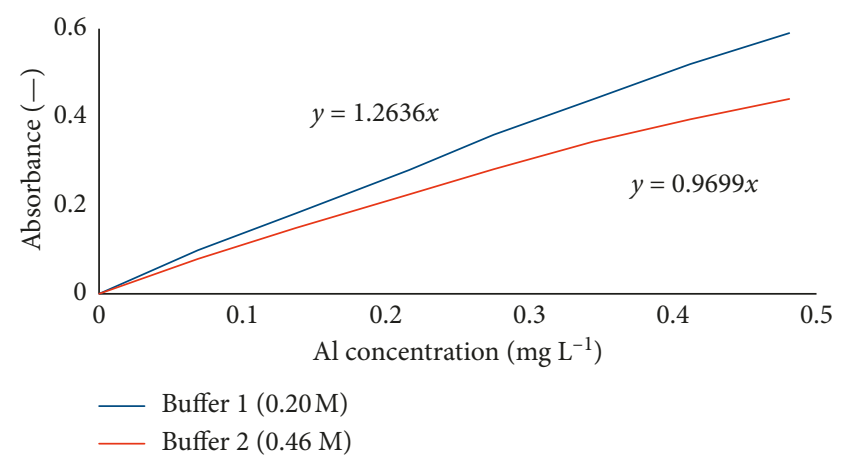

FIGURE 6: Influence of acetate buffer concentrations on absorbance.

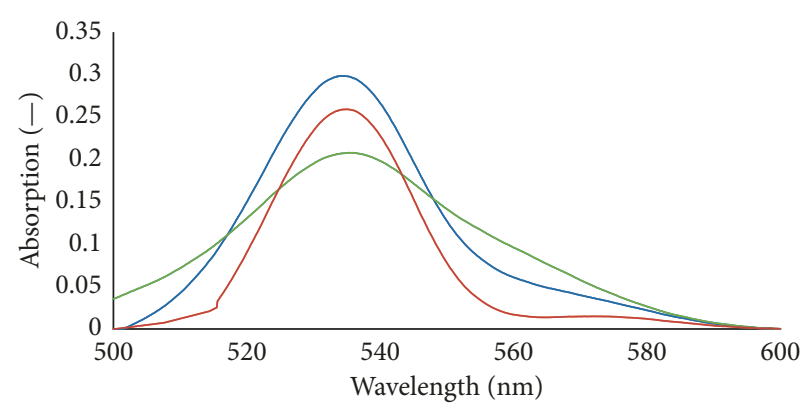

FIgURE 7: Spectra of Al-ECR complexes at various concentrations of acetate buffer and $\mathrm{pH}$, in relation to blank probe: blue, 5.2; orange, 5.5; green, $4.9 ; \mathrm{Al}^{3+}\left(7.4 \cdot 10^{-2} \mathrm{mM}\right)$.

oxidation acids were evaporated at the end. The $\mathrm{pH}$ of samples was adjusted to value 6.3 by addition of acetate buffer.

Figure 8 shows differences between the slopes of calibration curves. In real samples, the organic matrix components interact with aluminum. The compounds of aluminum and organic matter have often greater stability than the complex of aluminum and the eriochrome cyanine $\mathrm{R}$ [14]. Additionally, there was the intensification of interactions of different ions, which appeared in samples as a consequence of mineralization process. As a result, there is a decrease in the signal of $\mathrm{Al}(\mathrm{ECR})_{3}$ complex. The absorbance signals of curve 2 and 3 were lower against the standard calibration curve 1 . 


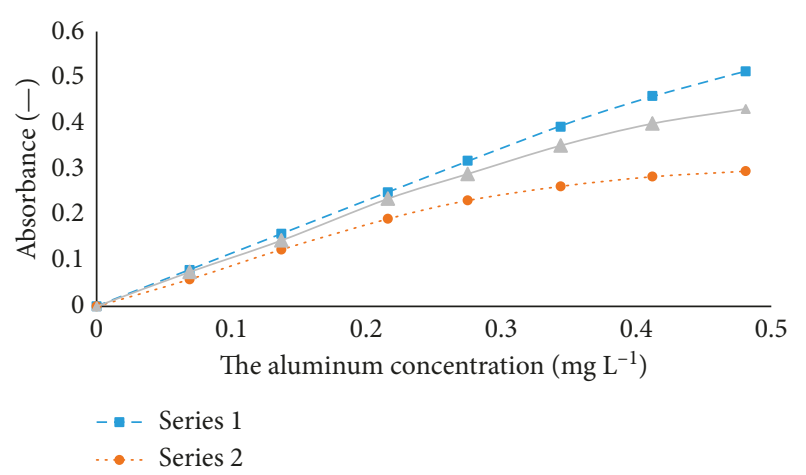

Figure 8: Dependence between absorbance and aluminum concentration.

3.4. The Graphite Furnace Atomic Adsorption Spectroscopy. Determination of aluminum content in samples by GFAAS brings a lot of difficulties in implementing the analysis. The first experimental problem is the purity of reagents used to measurements. Only high analytical grade reagents could be applied to avoid interferences of different ions and influence of aluminum contained in that. Many analyses have shown that this problem occurs for the first step when calibration curve was prepared.

The quality and the lifetime of graphite tube are particularly important because many analyses on the same tube lead to irremediable adsorption of trace content aluminum on the tube surface. The optimum number of measurement with a single tube is difficult to estimate because it depends on the aluminum concentration in measured samples [23].

The next problem is a prerequisite for homogeneity of the sample [24]. GFAAS is a very sensitive method, where fluctuations in local concentrations of aluminum result from the aluminum binding by hydrophobic organic compounds such as ligands. It leads to rejection of analytical results.

3.5. Comparison of GFAAS and ECR Colorimetric Method. The analyzed samples, both supernatant and solid sludge, have a complex chemical composition, and substantial matrix effects are very likely. The interfering effect of matrix components can be minimalized by the samples' mineralization and using standard addition calibration method. For this reason, the aluminum determination by atomic absorption spectrometry and by colorimetric method with ECR ligands was evaluated.

Results of aluminum concentration analyses in samples of mineralized supernatant for both measurement methods were compared. A calibration curve was prepared with the addition of $20 \mathrm{~mL}$ of mineralized supernatant, analogously to the previously described procedure (p. 3.1.3). A calibration curve for GFAAS was also prepared, according to the Polish Standard [7], for the aluminum standard and for mineralisate with the addition of standard at 5 -fold dilution of the samples, so that the aluminum concentrations ranged from $0.05 \mathrm{mg} \cdot \mathrm{L}^{-1}$ to $0.5 \mathrm{mg} \cdot \mathrm{L}^{-1}$. For prepared samples, a 3-fold measurement was made. The obtained results indicate that deviations from the actual signal value increase with the increase of the concentration of matrix components. The main reason of the increase in the deviation from the true absorbance value is the increase of the ionic strength of solutions.

Figure 9 shows the difference between the reading value (rhombus red dashed line for GFAAS method and square blue dashed line for colorimetric complex method) and the real the aluminum concentration in the studied supernatant liquid (green line). The red and yellow columns (from GFAAS and $\mathrm{Al}(\mathrm{ECR})_{3}$, respectively) in the bottom shows deviation from the real aluminum content in percent standard deviation scale. The colorimetric method read-out results are lower in the whole measuring range compared to real contents.

It should be noted that similar results can be obtained for samples of mineralized supernatant liquid, when the concentration of $\mathrm{Al}^{+3}$ ions is up to $0.25 \mathrm{mg} \cdot \mathrm{L}^{-1}$. Based on the analyses, it can be concluded that the GFAAS method better determines the actual content in the samples than the $\mathrm{Al}(\mathrm{ECR})_{3}$ method.

3.6. Adsorption Study. Experiments were conducted to determine the adsorptive capacity of activated sludge towards aluminum. The sewage sludge was prepared by washing several times with deionized water to remove the impurities and then filtration through standard filter papers. The sludge was mixed with water by the magnetic stirrer. The aluminum concentration in filtrate samples for each batch never exceeded $15 \mu \mathrm{g} \cdot \mathrm{L}^{-1}$, and they could be treated as a blank sample. Such low aluminum concentrations could be determined only by GFAAS.

About $0.1 \mathrm{~g}$ of activated sludge (dry weight) was shaken with $100 \mathrm{~mL}$ of aluminum solutions of various concentrations in the range $10-170 \mathrm{mg} \cdot \mathrm{L}^{-1}$, for a contact time of $5 \mathrm{~h}$. Aluminum was used in the form of various chemical compounds listed below. The solutions were filtered and the supernatants were analyzed for $\mathrm{Al}$ residues using FAAS method. The adsorption efficiency was calculated by dividing the amount of adsorbed metal by the mass of activated sludge.

Figure 10 indicates high adsorption of aluminum in the form of sulphate at a $\mathrm{pH}$ of about 4.5 (yellow line). A neutralization of the solution by sodium hydroxide to $\mathrm{pH}$ about 7.0 leads to the formation of insoluble aluminum hydroxide $\mathrm{Al}(\mathrm{OH})_{3}$, and it causes almost total metal adsorption (blue line). The analyzed samples measured by GFAAS method gives aluminum concentration read-outs below $0.05 \mathrm{mg} \cdot \mathrm{L}^{-1}$. The same samples analyzed by FAAS give unreal aluminum content in level exceeding $0.4 \mathrm{mg} \cdot \mathrm{L}^{-1}$. The flame atomic absorption spectrometry gives reproducible results for the aluminum concentration above $5 \mathrm{mg} \cdot \mathrm{L}^{-1}$.

The use of acidic coagulants type PAX 25 (green line) and PAX 19H (purple line) shows lower adsorption because $\mathrm{pH}$ value of tested samples is low in the range of $3.5 \pm$ 0.3 . The aluminum adsorption for PAX $19 \mathrm{H}$ is particularly low and does not exceed $10 \mathrm{mg} \cdot \mathrm{L}^{-1}$. It showed also worst 


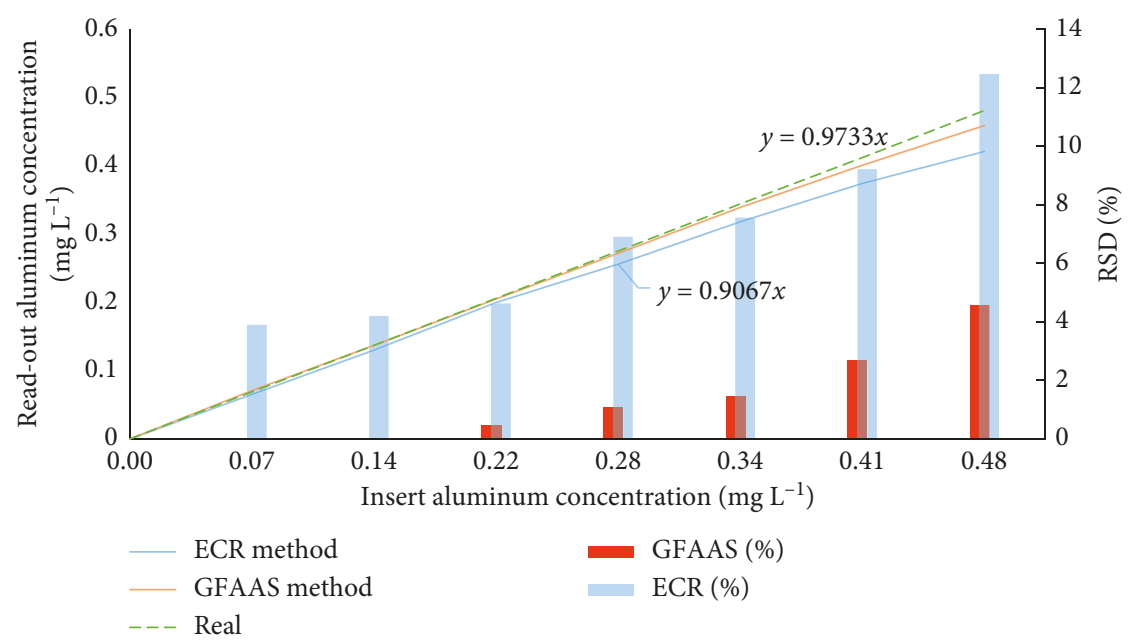

FIGURE 9: Comparison of GFAAS aluminum concentration determinations and colorimetric method in relation to the actual value.

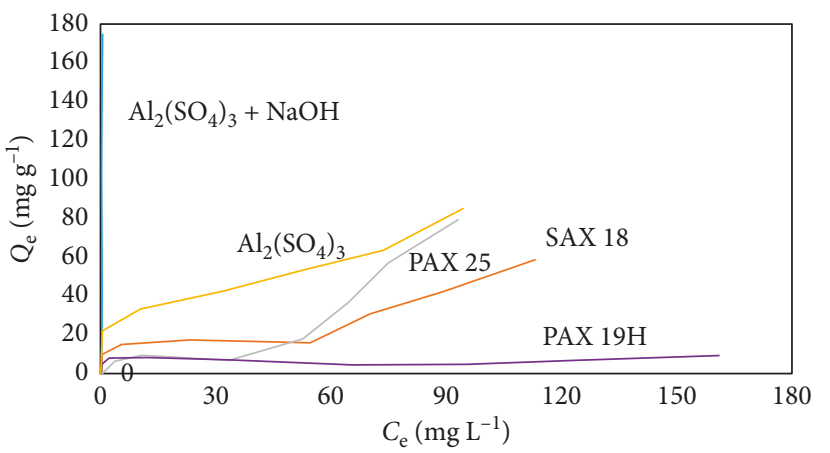

Figure 10: Adsorption of aluminum by sludge for different types of coagulants.

sludge sedimentation, probably due to higher solution acidity [25]. The samples with the addition of the alkaline coagulant SAX 18 (red line) showed $\mathrm{pH}$ value from 6.5 to 9.5. For SAX 18 , aluminum adsorption efficiency incipiently was better, but in final coagulants, doses were much worse in comparison with PAX 25 (reaction sample close to 3.5).

It should be noted that both aluminum sulphate and PAX 25, at a dose exceeding $10 \mathrm{mg} \cdot \mathrm{L}^{-1}$ aluminum, show an acidic $\mathrm{pH}$ of the solution of similar value. Then, acidic forms of aluminum $\mathrm{Al}\left(\mathrm{OH}_{2}\right)_{6}{ }^{+3}$ and $\mathrm{AlOH}\left(\mathrm{OH}_{2}\right)_{5}{ }^{+2}$ are formed [26]. So, such large differences in the adsorption of aluminum by sludge must therefore be caused by differences in the structure of aluminum compounds used, i.e., polyaluminum chloride. In the case of basic SAX 18, the $\mathrm{pH}$ value of the solution increases, leading to the formation of soluble aluminum forms such as $\mathrm{Al}(\mathrm{OH})_{2}{ }^{+}$. Hence, the conclusion is that ionic reactions have a significant role in the sorption of aluminum by the activated sludge during the coagulation process.

The sorption of aluminum dependent on dosed coagulant type is an important but not the only factor affecting the efficiency of sewage sludge treatment. It should also take into account such measures of treated wastewater as TOC, TN, NTU, size, and viscosity of the resulting aggregates of sludge.

\section{Conclusions}

Wastewater produced in dairy plants is commonly treated with aluminum sulphate or polyaluminum chloride coagulants. They enhance sedimentation rate of organic matter component. This paper evaluates common methods for the determination of aluminum concentration in wastewater. The main results are summarized as follows.

Considering the measuring range of used analytical methods, the GFAAS allows detection of the aluminum content in samples ranging from 0.01 to $0.1 \mathrm{mg} \cdot \mathrm{L}^{-1}$, but analysis of mineralized samples can be stretched to range up to $0.5 \mathrm{mg} \cdot \mathrm{L}^{-1}$ by diluting 5 times in very good effect. Increasing the dilution multiplicity leads to a reduction in the accuracy of the results to an unacceptable level. Colorimetric analysis can give similar results to GFAAS within range up to $0.25 \mathrm{mg} \cdot \mathrm{L}^{-1}$. The detection range of aluminum content in sludge samples can be extended up to $2.0 \mathrm{mg}$ in the case of mineralized and diluted samples, but read-out results were indicative. Whereas the FAAS method is recommended for samples with a aluminum concentration of 5 to $100 \mathrm{mg} \cdot \mathrm{L}^{-1}$. At low aluminum concentrations, less than $4 \mathrm{mg} \cdot \mathrm{L}^{-1}$, the accuracy of the assay is unsuitable for FAAS. The detection limits determined in this work were, respectively, $0.02 \mathrm{mg} \cdot \mathrm{L}^{-1}$ for GFAAS method, $0.07 \mathrm{mg} \cdot \mathrm{L}^{-1}$ for colorimetric method, and $4.0 \mathrm{mg} \cdot \mathrm{L}^{-1}$ for FAAS.

The aluminum absorbance depends on the samples' $\mathrm{pH}$ and the form of aluminum which is introduced into the system. Aluminum hydroxide is not fully atomized at temperatures generated in the standard acetylene flame. It has to be raised by the addition of $\mathrm{N}_{2} \mathrm{O}$. The flame atomic absorption spectrometry gives reproducible results for the aluminum concentration above $5 \mathrm{mg} \cdot \mathrm{L}^{-1}$, and it was too high to compare the aluminum content with other methods for the same analyzed samples. Therefore, it is necessary to analyze supernatant samples using both types of atomic absorption spectrometry, when an analyte content fluctuates between one of the detection limit scales.

In the colorimetric method, the absorbance value depends not only on the aluminum concentration but also on 
the reaction time and $\mathrm{pH}$. A simple modification of the colorimetric method, consisting in adjustment of suitable buffer capacity of the sample, allows to determine the aluminum content in sewage sludge after its acidic mineralization. To neutralize acidity impact, it is necessary to use the stronger acetate buffer $(0.46 \mathrm{mM})$, which protected eriochrome cyanine $\mathrm{R}$ before the decomposition.

The low value of $\mathrm{pH}$ decreased the absorbance. High acetate buffer concentrations led to absorption decrease, despite the relatively high $\mathrm{pH}$ value of the sample. We speculate that high ionic strength of the acetate buffer hampered the aluminum complex formation.

Determination of aluminum content in samples by GFAAS is a more challenging method. Particular attention should be paid to the inhomogeneity of analyzed samples which may lead to substantial absorption intensity variations. Reagents of high analytical grade, ultra pure water, and high quality graphite tube should be applied.

Determination of aluminum content by spectrophotometric method may be a useful and cheap alternative for analyses carried out by atomic adsorption spectroscopies, especially when concentrations of an analyte at the upper limit of the GFAAS or the lower limit of the FAAS are concerned. However, it should be noticed that atomic absorption spectrometry determines the total content of aluminum either in a free ionic or complexed forms. The latter may be characterized by lower stability than the $\mathrm{Al}(\mathrm{ECR})_{3}$.

\section{Data Availability}

The data used to support the findings of this study are available from the corresponding author upon reasonable request.

\section{Conflicts of Interest}

The authors declare that they have no conflicts of interest.

\section{Acknowledgments}

The authors wish to thank Mr. Jakub Kubicki (Institute of General and Ecological Chemistry, Lodz University of Technology) and Mrs. Jadwiga Albińska (Institute of General and Ecological Chemistry, Lodz University of Technology) for technical assistance.

\section{References}

[1] M. Kuliś and A. Tylkowska-Siek, Fizyczne Rozmiary Produkcji Zwierzęcej w 2015 r, Główny Urząd Statystyczny, Departament Rolnictwa, Warsaw, Poland, 2016.

[2] D. Boruszko and W. Dąbrowski, "Badania efektywności procesu flotacji i właściwości osadów poflotacyjnych $\mathrm{z}$ podczyszczania ścieków mleczarskich," Inżynieria i Ochrona Środowiska, vol. 17, no. 2, pp. 269-280, 2014.

[3] K. Szwedziak, "Charakterystyka osadów ściekowych i rolnicze wykorzystanie,” Inzynieria Rolnicza, vol. 4, pp. 297-302, 2006.

[4] J. B. Bień and K. Wystalska, "Energetyczne wykorzystanie osadów ściekowych," Przemyst Chemiczny, vol. 94, no. 9, pp. 1496-1499, 2008.
[5] D. Hawke, J. Powell, and S. Simpson, "Equilibrium modelling of interferences in the visible spectrophotometric determination of aluminium(III): comparison of the chromophores chrome azurols, eriochrome cyanine $\mathrm{R}$ and pyrocatechol violet, and stability constants for eriochrome cyanine R-aluminium complexes," Analytica Chimica Acta, vol. 319, no. 3, pp. 305-314, 1996.

[6] W. Dougan and A. Wilson, "The absorptiometric determination of aluminium in water. A comparison of some chromogenic reagents and the development of an improved method," Analyst, vol. 99, no. 1180, pp. 413-430, 1974.

[7] Polish Standard, Jakość Wody-Oznaczanie Glinu-Metody Atomowej Spektrometrii Absorpcyjnej, PN-EN ISO 12020, Polish Standard, Warsaw, Poland, 2002.

[8] A. Shokrollahi, M. Ghaedi, M. S. Niband, and H. R. Rajabi, "Selective and sensitive spectrophotometric method for determination of sub-micro-molar amounts of aluminium ion," Journal of Hazardous Materials, vol. 151, no. 2-3, pp. 642-648, 2008.

[9] A. G. G. Dionisio, A. M. Dantas de Jesus, R. S. Amais et al., "Old and new flavors of flame (furnace) atomic absorption spectrometry," International Journal of Spectroscopy, vol. 2011, Article ID 262715, 30 pages, 2011.

[10] Polish Standard, Oznaczanie Glinu Metoda $z$ Eriochromocyjanina R, PN-C-04605-02, Polish Standard, Warsaw, Poland, 1992.

[11] W. Hermanowicz, J. Dojlido, and W. Dożańska, FizycznoChemiczne Badanie Wody i Ścieków, Arkady, Warsaw, Poland, 1999.

[12] W. Siriangkhawut, S. Tontrong, and P. Chantiratikul, "Quantitation of aluminium content in waters and soft drinks by spectrophotometry using eriochrome cyanine R," Research Journal of Pharmaceutical, Biological and Chemical Sciences, vol. 4, no. 3, pp. 1154-1161, 2013.

[13] B. Perkin-Elmer, Analytical Methods for Atomic Absorption Spectroscopy, The Perkin-Elmer Corp., Norwalk, CT, USA, 1996.

[14] I. Narin, M. Tuzen, and M. Soylak, "Aluminium determination in environmental samples by graphite furnace atomic absorption spectrometry after solid phase extraction on Amberlite XAD-1180/pyrocatechol violet chelating resin," Talanta, vol. 63, no. 2, pp. 411-418, 2004.

[15] J. Tria, E. C. V. Butler, P. R. Haddad, and A. R. Bowie, "Determination of aluminium in natural water samples," Analytica Chimica Acta, vol. 58, no. 2, pp. 153-165, 2007.

[16] C. L. Craney, K. Swartout, F. W. Smith, and C. D. West, "Improvement of trace aluminum determination by electrothermal atomic absorption spectrophotometry using phosphoric acid," Analytical Chemistry, vol. 58, no. 3, pp. 656-658, 1986.

[17] C. Marin, A. Tudorache, and L. Vladescu, "Aluminium determination and speciation modelling in groundwater from the area of a future radioactive waste repository," Revistade Chimie (Bucharest), vol. 5, pp. 431-438, 2010.

[18] Agilent, Technical Overview, The Role of Chemical Modifiers in Graphite Furnace Atomic Absorption Spectrometry, 59919286EN, Agilent, Santa Clara, CA, USA, 2018.

[19] P. Bermejo-Barrera, E. Beceiro-Gonźalez, and A. BermejoBarrera, "Use of Pd- $\mathrm{Mg}\left(\mathrm{NO}_{3}\right)_{2}$ as matrix modifier for the determination of aluminum in water by electrothermal atomization atomic absorption spectrometry," Microchemical Journal, vol. 45, no. 1, pp. 90-96, 1992.

[20] L. M. Voth-Beach and D. E. Shrader, "Investigations of a reduced palladium chemical modifier for graphite furnace 
atomic absorption spectrometry," Journal of Analytical Atomic Spectrometry, vol. 2, no. 1, pp. 45-50, 1987.

[21] S. Noremberg, M. Veiga, D. Bohrer et al., "Determination of aluminum and silicon in bovine liver by graphite furnace atomic absorption spectrometry after dissolution with tetramethylammonium hydroxide," Analytical Methods, vol. 7, no. 2, 2014.

[22] L. Pszonicki and A. M. Essed, "Palladium and magnesium nitrate as modifiers for the determination of lead by graphite furnace atomic absorption spectrometry," Chemia Analityczna (Warsaw), vol. 38, pp. 771-778, 1993.

[23] R. Sturgeon, "Graphite furnace atomic absorption spectrometry: fact and fiction," Fresenius' Zeitschrift für analytische Chemie, vol. 324, no. 8, pp. 807-818, 1986.

[24] N. R. Bader and B. Zimmermann, "Sample preparation for atomic spectroscopic analysis: an overview," Advances in Applied Science Research, vol. 3, pp. 1733-1737, 2012.

[25] X. H. Guan, G. H. Chen, and C. Shang, "ATR-FTIR and XPS study on the structure of complexes formed upon the adsorption of simple organic acids and aluminum hydroxide," Journal of Environmental Sciences, vol. 19, no. 4, pp. 438-443, 2007.

[26] J. D. Hem and C. E. Roberson, "Form and Stability of aluminum hydroxide complexes in dilute solution," in Chemistry of Aluminum in Natural Water, Geological Survey WaterSupply Paper 1827-A, United States Government Printing Office, Washington, DC, USA, 1967. 

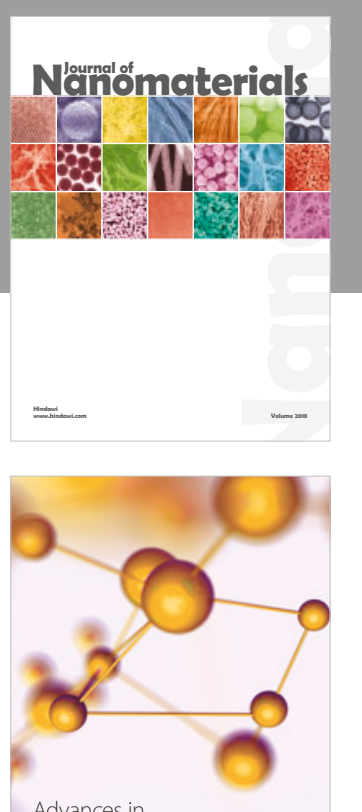

Physical Chemistry
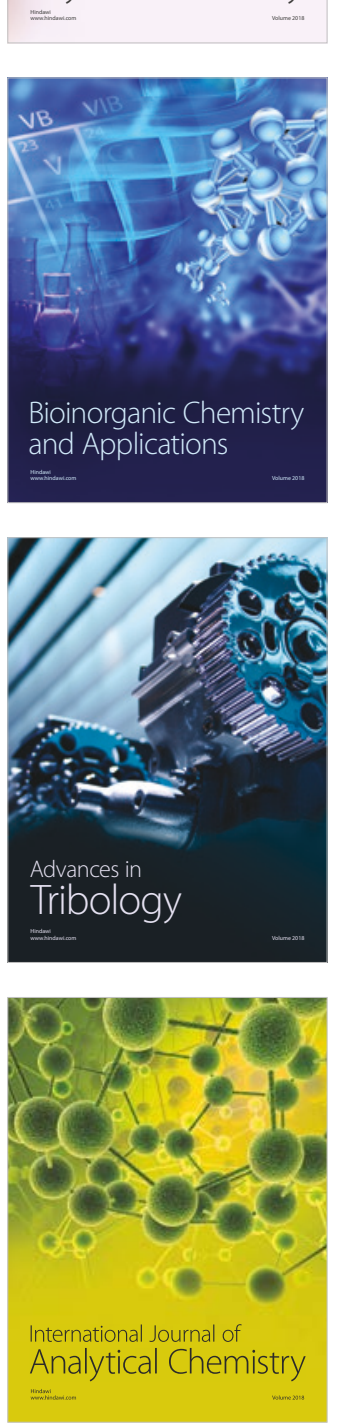

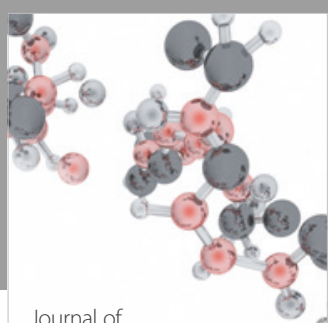

Analytical Methods

in Chemistry

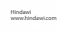

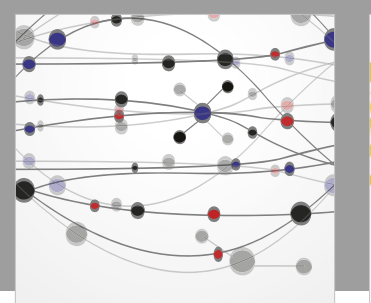

The Scientific World Journal

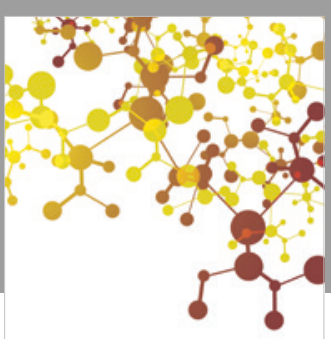

Journal of

Applied Chemistry
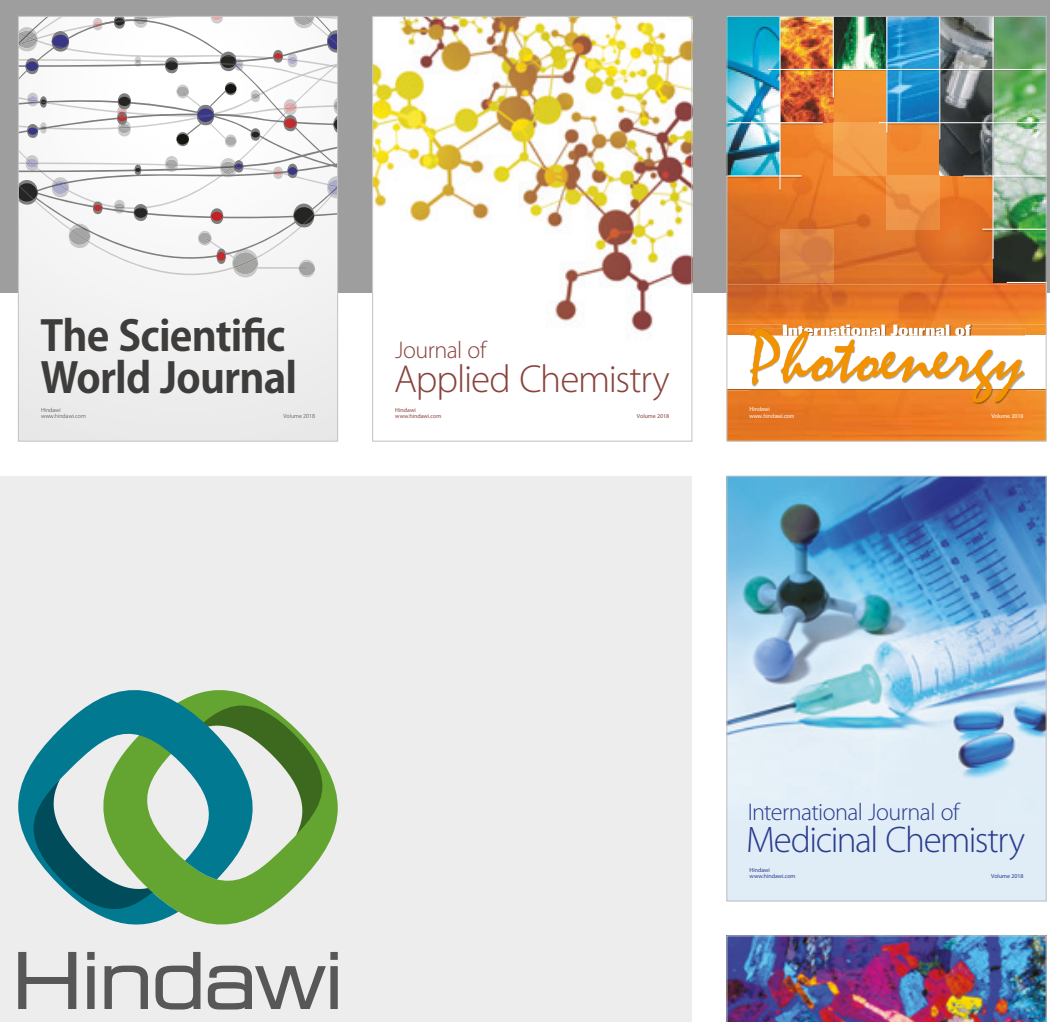

Submit your manuscripts at

www.hindawi.com
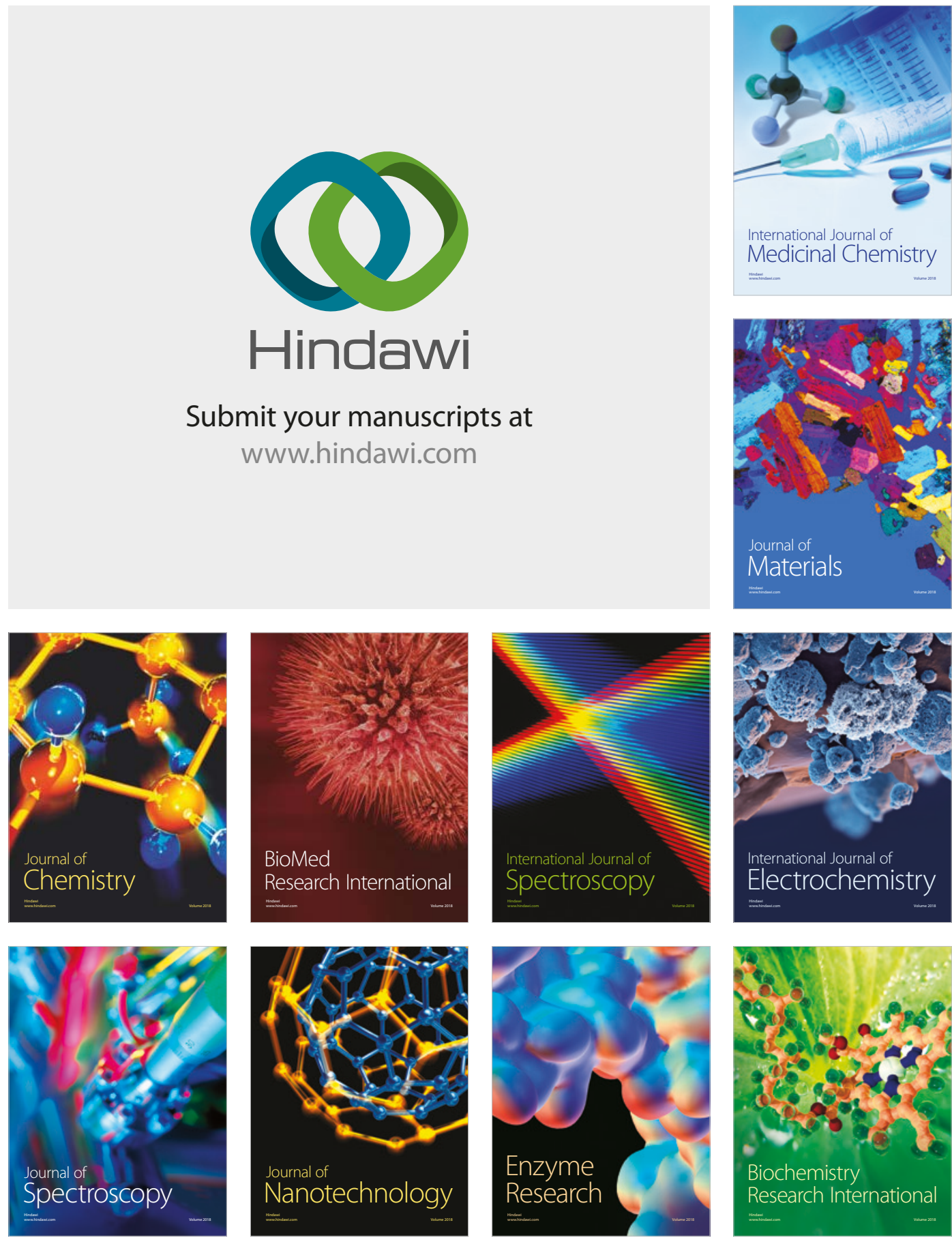
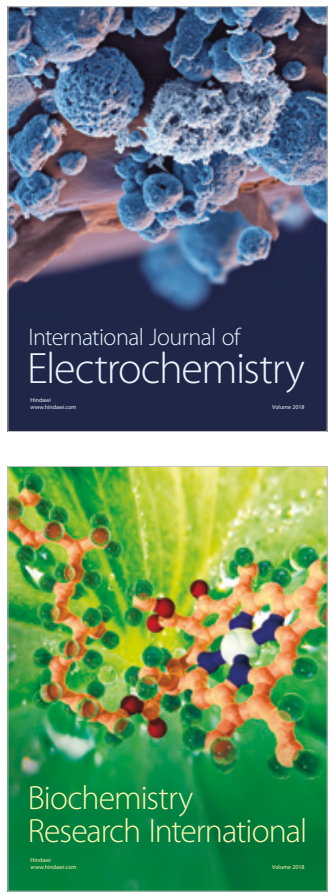